\title{
Some edaphic properties in Dicranopteris linearis dominated landscape:A perspective for restoration success
}

\section{R. Liyanage, T. Kariyawasam, T. Wijewickrama, J. Bandara and S. Madawala*}

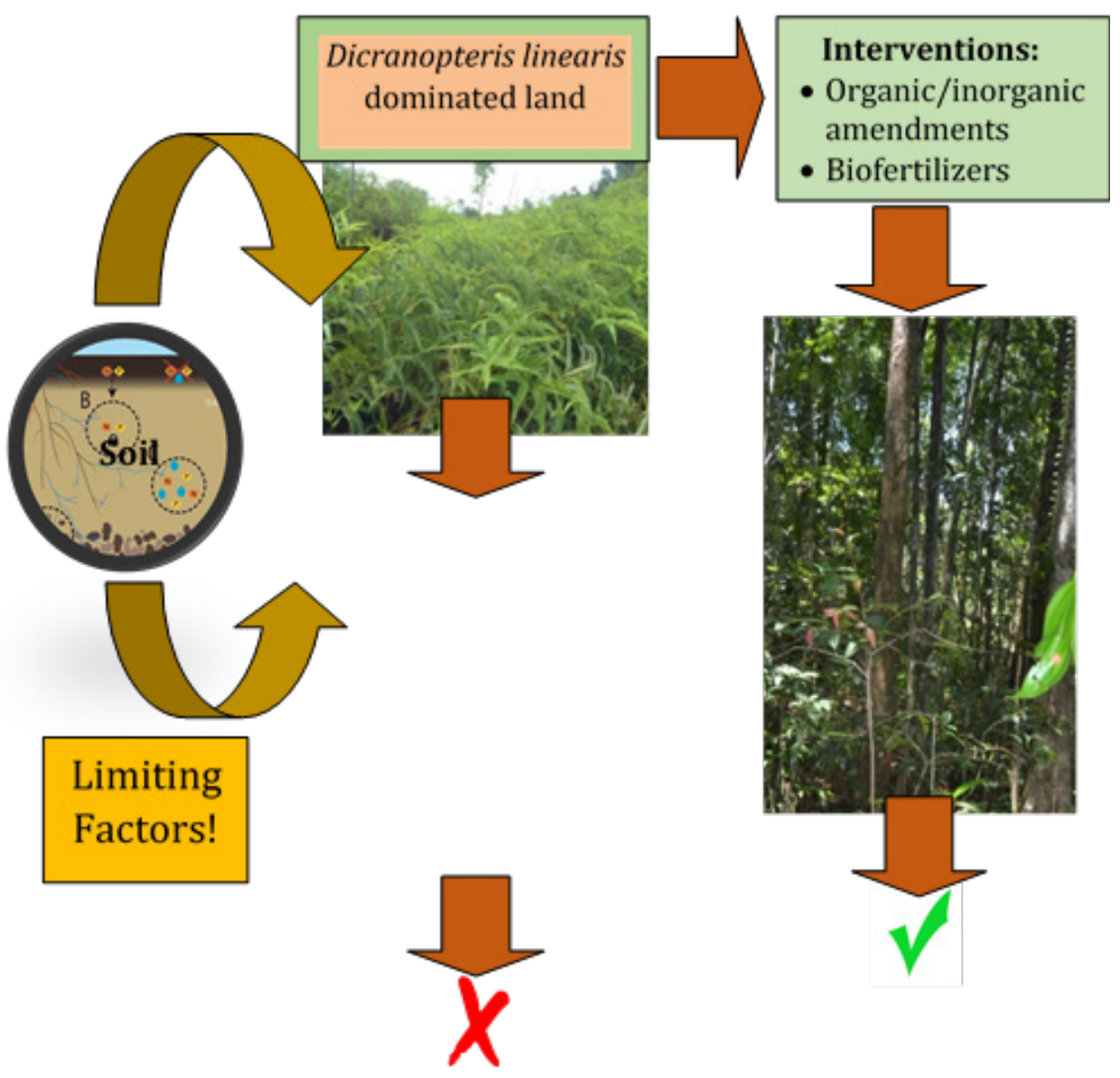

\section{Highlights}

- Often, Dicranopteris linearis dominated lands attempt to restore after complete removal or strip cut, but with minimal success rates.

- Despite edaphic resources playing a critical role in seedling growth and establishment, soil-related factors always overlook in restoration trials.

- The study highlights the importance of evaluating edaphic resources prior introducing restoration measures in fern-dominated lands.

- Addition of soil amendments (chemical- and bio-fertilizers) could be practiced in order to ameliorate edaphic conditions prior introducing restoration measures. 
RESEARCH ARTICLE

\title{
Some edaphic properties in Dicranopteris linearis dominated landscape:A perspective for restoration success
}

\author{
R. Liyanage, T. Kariyawasam, T. Wijewickrama, J. Bandara and S. Madawala* \\ Department of Botany, Faculty of Science, University of Peradeniya, Peradeniya, Sri Lanka.
}

Received: 21/07/2020; Accepted:13/01/2021

\begin{abstract}
Land degradation is a global challenge leading to loss of biodiversity and ecosystem services. The ever-increasing population and developmental activities make it hard to confine; thus, restoration of highly degraded habitats is the only solution to lessen its impacts. Despite many restoration efforts to bring back the original glory to highly degraded habitats, majority of them are ended up in futility due to direct and/or indirect causes. Dicranopteris linearis is identified as a noxious weed prevalent in highly disturbed sites. Though the physical removal of the fern is known as a way to assist natural succession, the attempts to restore these fern-dominated landscapes in other parts of the tropics showed limited achievements. International Union for Conservation of Nature (IUCN) in Sri Lanka carried out a pilot project in order to revert these fernlands back to forests by transplanting native species following strip cutting. However, transplanted seedlings show rather poor growth with no apparent sign of successful finale. The lack of edaphic resources is considered as a major limiting factor behind landscape recovery following disturbances. The present study evaluated some edaphic resources (soil nutrients and arbuscular mycorrhizal fungi, AMF) in $D$. linearis dominated landscape to examine their implications for restoration success. Accordingly, a soil analysis was carried out in a fernland located in the buffer zone of the Kanneliya Forest Reserve (KFR) in Sri Lanka to quantify some chemical, physical, and biotic parameters. The results were compared with two reference sites nearby, a lowland tropical rainforest (LR) and a shrub-dominated land use (SD). The results revealed that despite few significant changes between the three land use types, their soils are generally of low fertility status. The fernlands (DD) also showed conspicuously a lower abundance, richness, and diversity of AMF community in comparison to the other two study sites. Therefore, the lack of soil chemical and biotic resources converts these fernlands into habitats with poor potential for revival on their own. Therefore, carefully selected interventions are needed (i.e., addition of an initial dosage of chemical, organic and/or biofertilizers) to enrich the edaphic environment prior to introducing native seedlings to convert these highly degraded fernlands into some form of vegetated landscape.
\end{abstract}

Keywords: restoration; fernlands; edaphic properties; Kanneliya Forest Reserve; Sri Lanka.

\section{INTRODUCTION}

In maintaining ecosystem functions, both above- and below-ground factors play crucial roles (Lovelock and Ewel, 2005). The restoration interventions often show low success rates due to both above- and below-ground factors including low seed availability, seed predation, fire, competition from the matrix vegetation, poor soil structure, lack of soil nutrients etc. (Uhl and Jordan, 1984; Uhl, 1988; Uhl et al., 1988; Lugo, 1988; Holl and Kappelle, 1999; Hardwick et al., 2004; Gunaratne et al., 2010; 2011 and 2014). Restoration interventions often yield futile endings as practitioners pay more attention to fulfill above-ground conditions with minimal focus on below-ground factors. It is a known fact that to achieve above-ground success, favorable below-ground conditions are critical. Therefore, a highly degraded landscape needs more interventions to ameliorate onsite conditions to stimulate and/or facilitate the recovery processes (Kollmann et al., 2016; Gomes et al., 2017). However, relatively few studies have been undertaken to explore the role of below-ground resources on the success of restoration efforts. In order to predict the restoration trajectory and to introduce effective restoration measures, it is important to understand both above- and below-ground factors that could limit the success of costly restoration efforts (Coutinho et al., 2015).

In Sri Lanka, the forest cover is diminishing at a rapid rate leaving once large expanses of forests into highly isolated fragments, which are inclined to further deterioration through human activities (Lindström et al., 2012; FAO, 2010a; GOSL, 2000). Deforestation is most widespread in wet and intermediate zones of the island where the forest remnants of the once widespread natural forest cover remain (FAO, 1997). Kanneliya Forest Reserve (KFR), a tropical lowland wet evergreen rainforest, is located in the Southern Province of Sri Lanka. KFR is one of the few remaining rainforest patches in the island, with high biodiversity (Jayasuriya and Abeywardhane, 2008). The forest edges and other disturbed habitats in the buffer zone of the KFR are dominated by an aggressive fern, Dicranopteris linearis (locally known as kekilla). This fern-dominated landscape has been persisted for decades or even centuries (Russell et al., 1998), due to its rapid growth and ability to endure frequent fires (Maheswaran 
and Gunatilleke, 1998). This rapid clonal growth helps to form a mat-like dense layer covering large expanses of open area (Russell et al., 1999), thus preventing natural regeneration (Cohen et al., 1995; Susanti et al., 2014; Akib et al., 2018; Weerasinghe et al., 2018). In addition to its light-loving nature, Dicranopteris is well-adapted to highly degraded conditions with poor soil resources. Dicranopteris is also known to incur allelopathic influence on other forest species (Ismail and Chong, 2009), while its litter is known to be highly recalcitrant (Amatangelo and Vitousek, 2009). These inherent traits of Dicranopteris adversely influence ecosystem processes such as tree regeneration, forest succession and nutrient cycling (TetVun and Ismail, 2006; Negishi et al., 2006; Zheng et al., 2008; Zhao et al., 2012). Attempts to revert these ferndominated landscape into forested areas are scarce, and even those yielded discouraging outcomes (Cohen et al., 1995; Zhao et al., 2012).

According to previous studies, physical removal has been identified as the only plausible action to restore ferndominated landscape (Cohen et al., 1995; IUCN, 2016), though it brings many practical difficulties. Recently, the fern-dominated land in the buffer zone of KFR was stripcut along contours and planted with native tree seedlings by the IUCN Sri Lanka. The tree seedlings showed a rather poor growth, possibly due to the lack of soil resources threatening the restoration efforts of Dicranopterisdominated landscape (personal communications). Thus, the mere removal of the fern may not be the best solution to revert fern-dominated landscape back to some form of vegetated habitat without improving edaphic conditions. The accumulation of highly recalcitrant Dicranopteris litter may influence the nutrient turnover rates over time. Nevertheless, comparatively few studies have been done so far to evaluate the impacts of Dicranopteris on edaphic properties, and how they influence the recovery process in restoration efforts (Zhao et al., 2013). Therefore, the status of edaphic resources in these fern-dominated landscapes will provide some important baseline information to introduce more effective restoration measures to convert these unproductive habitats back to tree-dominated areas. Thus, the main aim of the present study was to evaluate some below-ground resources in Dicranopteris-dominated landscape (DD). The results were then compared with edaphic properties of two other reference sites, a lowland rainforest (LR) and a shrub-dominated site (SD) located nearby. The findings of this study could provide some important baseline information to assess the restoration potential of these fernlands and to adopt appropriate restoration interventions to improve on-site edaphic conditions.

\section{MATERIALS AND METHODS}

\section{Study site description}

Kanneliya Forest Reserve (KFR) is located in the Galle District in the Southern Province of Sri Lanka (6 $6^{\circ} 15^{\prime}$ $\left.18.4998 " / \mathrm{N}, 80^{\circ} 22^{\prime} 24.2898 / \mathrm{E}\right)$. The area has a mean annual temperature of $27^{\circ} \mathrm{C}$ and a mean annual precipitation of 4,445 mm. The KFR, a part of a large rainforest complex with an area of approximately 5,306 ha, is located in the wet zone of the country (Bandaratillake, 2003). Despite its significance in terms of biodiversity (Singhakumara, 1995; Ekaratne et al., 2003), the area has a history of intense logging to provide raw material for plywood industry. Since 2001, these unwarranted activities have been decreased notably due to the demarcation of forest boundaries. Together with Nakiyadeniya and Dediyagala, KFR has been designated as an International Biosphere Reserve in 2004 by UNESCO, and it is home to many endemic plant and animal species (http://www.unesco.org/ $\mathrm{mabdb} / \mathrm{br} / \mathrm{brdir} /$ directory/database.asp).

The Dicranopteris dominated land (DD) is the most common land use type in the buffer zone of the KFR. For comparison, an undisturbed forest patch (LR), a lowland tropical rainforest, and a shrub-dominated (SD) site were selected from the near vicinity (Figure 1). The shrubdominated vegetation, also located in the buffer zone of the KFR, seems to be an early successional vegetation following some disturbances, though its origin is not clearly reported. The study sites are located approximately $1 \mathrm{~km}$ apart from each other and the field sampling was carried out in May 2019.

\section{Soil sampling}

From each land use type, 20 well represented soil samples (each sample is a composite of 4 soil samples taken $1 \mathrm{~m}$ apart from each other) were collected randomly using a spade with the help of a wooden $15 \times 15 \mathrm{~cm}$ quadrat (up to $0-15 \mathrm{~cm}$ depth). Before sampling soils, the thick litter layer in fernlands has been removed carefully in order to expose the mineral soils (Zhao et al., 2012). In other two sites too (SD and LR), the litter layer was removed before taking soil samples as the main aim of the study is to evaluate the edaphic resources of the mineral soils. In total, 60 soil samples were taken from all three study sites. Soil samples collected into labeled polythene bags were then transported to the Department of Botany, Faculty of Science, University of Peradeniya for further analyses. Approximately one half of each soil sample was air-dried by spreading in shallow plastic trays in a well-ventilated place protected from rain and wind. The air-dried soil samples were crushed gently to get rid of large lumps before sieving through a $2 \mathrm{~mm}$ mesh to remove any gravel and other debris. The sieved soil samples were stored in labeled paper bags. The other part of the soil sample was placed in a refrigerator for the analysis of biological parameters and available nutrients such as $\mathrm{NO}_{3}^{-}-\mathrm{N}$ and $\mathrm{PO}_{4}^{3-}-\mathrm{P}$.

The soil samples were analyzed for chemical and physical parameters such as exchangeable cations ( $\mathrm{Ca}, \mathrm{Fe}$, $\mathrm{K}, \mathrm{Mg}, \mathrm{Na}$ ), organic carbon, $\mathrm{NO}_{3}^{-}-\mathrm{N}$, available phosphorus, soil $\mathrm{pH}(1: 1.5 \mathrm{w} / \mathrm{v}$ ratio of soil: distilled water), soil texture (feel method by USDA) and soil colour using standard procedures (Van Reeuwijk, 1993). The soil moisture was analyzed using the gravimetric method. For exchangeable cations, Atomic Absorption Spectrophotometer was used with appropriate standards. Organic C, available N and P analyzed using colorimetric methods. 


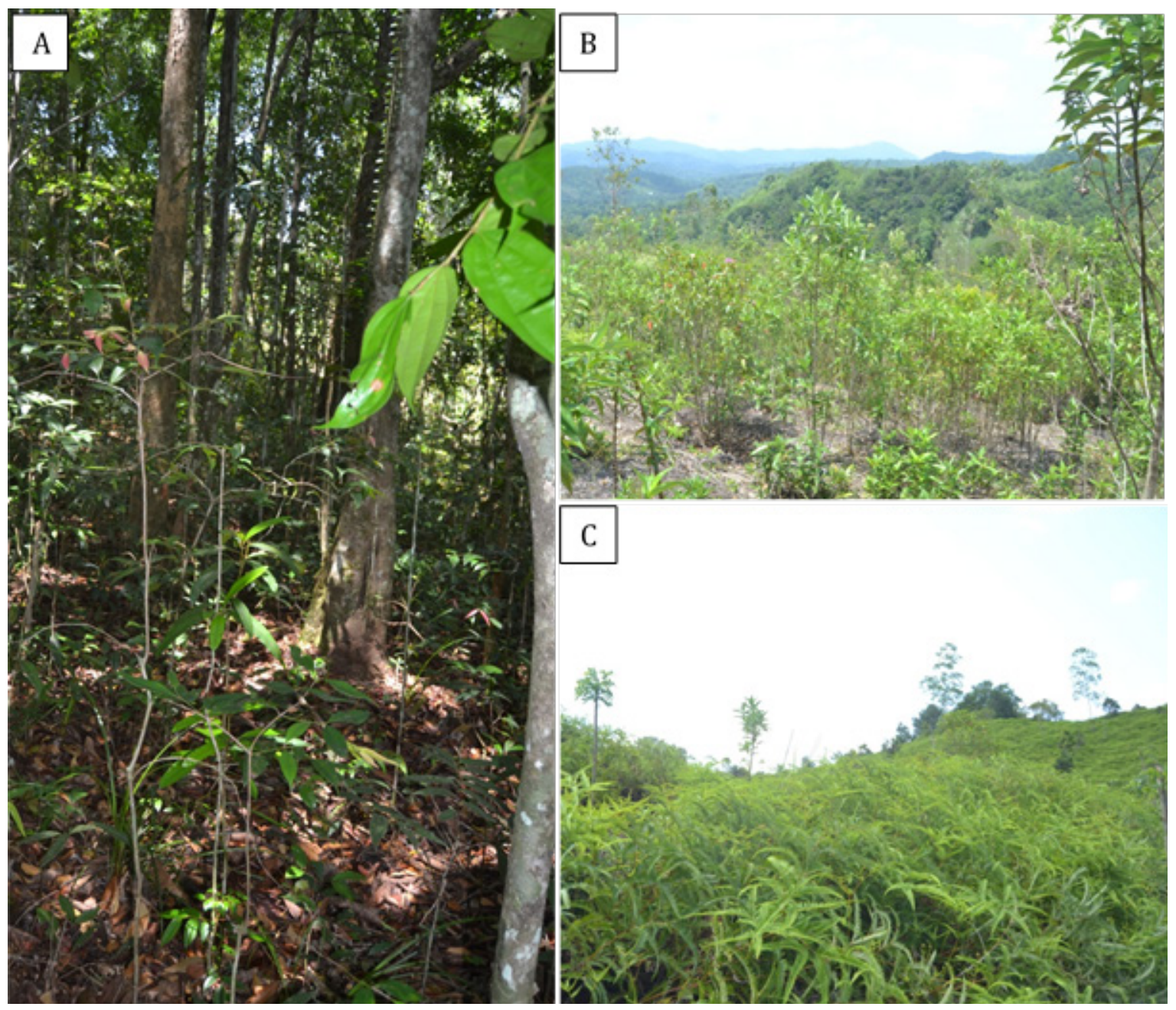

Figure 1: The three land use types used in the study are; A - lowland rainforest (LR), B - shrub-dominated site (SD) and C Dicranopteris-dominated fernland (DD) in Kanneliya Forest Reserve, Sri Lanka.

\section{AMF spore abundance and richness}

AMF spore abundance and richness were determined using the wet sieving and decanting method described by Brundett et al. (1996). Approximately, $100 \mathrm{~g}$ field-fresh soil sample was used to extract the spores on to filter papers. Using a compound microscope, the number of spores was counted and morphotypes were identified using spore wall characteristics, appendages and colour with the help of INVAM (https://invam.wvu.edu/).

\section{Statistical analysis}

Data on mean density and richness of AMF spores were compared among sites using one- way $\operatorname{ANOVA}(n=10)$. Soil properties were too compared by using one- way ANOVA. Mean separations were done using Tukey's test at the 0.05 level of significance. All data were checked for normality using Anderson-Darling test to meet ANOVA assumptions. All statistical analyses were performed by using Minitab (version 17.0) software. Diversity and similarity indices (Shannon-Wiener and Jaccard indices, respectively) were calculated using the data gathered. Principal Component Analysis was carried out by using the statistical software Canoco 5.

\section{RESULTS}

\section{Soil physical and chemical characteristics}

The soil was darker in colour at DD in comparison to other two sites, while the texture was similar in all three sites. This dark colouration in soil is resulted due to the buildup of organic matter owed to the recalcitrant nature of Dicranopteris litter. However, the SD showed the highest soil organic carbon content among the three land use types. The soil $\mathrm{pH}$ was significantly higher in SD and DD in comparison to the LR. Soil available N was higher in the LR than in SD and DD, though the soil phosphorus availability did not vary significantly among sites. Most cations are significantly higher in the fernland compared to the other two sites due to the lack of immobilization of cations in the highly recalcitrant litter layer (Table 1). 
Table 1: Mean values $( \pm \mathrm{SEM})$ of some soil chemical and physical characteristics of the three land use types, Dicranopterisdominated (DD), lowland rainforest (LR) and shrub-dominated (SD), at Kanneliya Forest Reserve in Sri Lanka. Different letters indicate significant differences between means of different land use types

\begin{tabular}{|c|c|c|c|}
\hline Soil Parameters & $\begin{array}{l}\text { Lowland Rainforest } \\
\text { (LR) }\end{array}$ & $\begin{array}{c}\text { Shrub-dominated site } \\
\text { (SD) }\end{array}$ & $\begin{array}{c}\text { Dicranopteris-dominated site } \\
\text { (DD) }\end{array}$ \\
\hline \multirow[t]{2}{*}{ "Soil Colour } & $10 \mathrm{YR} 2 / 2$ & $10 Y R 3 / 3$ & $5 Y 2.5 / 1$ \\
\hline & Very Dark Brown & Dark Brown & Black \\
\hline Soil texture & Clay loam & Clay loam & Clay loam \\
\hline Soil pH & $4.86(0.05)^{\mathrm{b}}$ & $5.36(0.02)^{\mathrm{a}}$ & $5.27(0.02)^{\mathrm{a}}$ \\
\hline Soil Moisture (\%) & $31.1(0.77)^{\mathrm{a}}$ & $25.3(1.33)^{\mathrm{ab}}$ & $28.0(0.79)^{\mathrm{b}}$ \\
\hline Available P (mg/g) & $0.505(0.190)^{\mathrm{a}}$ & $0.512(0.180)^{\mathrm{a}}$ & $0.493(0.193)^{\mathrm{a}}$ \\
\hline Organic C (\%) & $2.55(0.109)^{\mathrm{b}}$ & $3.50(0.092)^{\mathrm{a}}$ & $2.75(0.133)^{b}$ \\
\hline Nitrate-N (mg/g) & $0.988(0.029)^{\mathrm{a}}$ & $0.751(0.018)^{\mathrm{b}}$ & $0.758(0.024)^{\mathrm{b}}$ \\
\hline $\mathrm{Ca}(\mathrm{mg} / \mathrm{kg})$ & $100.1(14.14)^{\mathrm{ab}}$ & $88.4(5.34)^{\mathrm{b}}$ & $126.8(6.66)^{\mathrm{a}}$ \\
\hline $\mathrm{Fe}(\mathrm{mg} / \mathrm{kg})$ & $36.9(1.03)^{\mathrm{a}}$ & $30.1(0.40)^{\mathrm{b}}$ & $34.7(0.72)^{\mathrm{a}}$ \\
\hline $\mathrm{K}(\mathrm{mg} / \mathrm{kg})$ & $50.8(1.77)^{\mathrm{b}}$ & $59.5(4.59)^{\mathrm{b}}$ & $139.2(5.29)^{\mathrm{a}}$ \\
\hline $\mathrm{Mg}(\mathrm{mg} / \mathrm{kg})$ & $46.7(1.88)^{\mathrm{c}}$ & $60.2(2.79)^{\mathrm{b}}$ & $75.7(2.27)^{\mathrm{a}}$ \\
\hline $\mathrm{Na}(\mathrm{mg} / \mathrm{kg})$ & $249(17.9)^{\mathrm{a}}$ & $236(3.19)^{\mathrm{a}}$ & $267(4.70)^{\mathrm{a}}$ \\
\hline
\end{tabular}

Letters indicate significant differences using Tukey's Honest Significant Differences for data reported in rows.

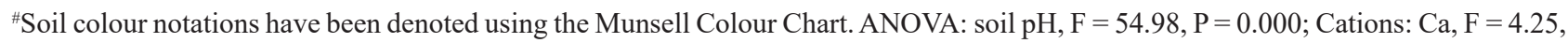
$\mathrm{P}=0.021 ; \mathrm{Fe}, \mathrm{F}=20.70, \mathrm{P}=0.000 ; \mathrm{K}, \mathrm{F}=135.95, \mathrm{P}=0.000 ; \mathrm{Mg}, \mathrm{F}=38.32, \mathrm{P}=0.000$ and $\mathrm{Na}: \mathrm{F}=2.04, \mathrm{P}=0.143 ;$ soil moisture, $\mathrm{F}$ $=8.46, \mathrm{P}=0.001 ;$ Available $\mathrm{P}, \mathrm{F}=0.40, \mathrm{p}=0.671 ; \mathrm{NO}_{3}{ }^{-} \mathrm{N}, \mathrm{F}=31.21, \mathrm{p}=0.000 ;$ Organic $\mathrm{C}, \mathrm{F}=19.85, \mathrm{p}=0.000$.

\section{Abundance and richness of AMF spores}

The spore abundance and richness were significantly lower in the fern-dominated land (DD) in comparison to the reference habitats (LR and SD). The S-W Diversity index too showed the lowest in DD followed by SD and LR. The evenness values were close to 0.5 in all three land use types. The Jaccard indices showed lower similarity between LR and DD (24\%) than that of SD and DD (50\%) (Table 2).

Despite significant differences between land use types, their abundance and richness in terms of size categories did not show any consistent changes among study sites (Figures 2 and 3). However, the mean spore abundance varied more in SD in comparison to other two sites, LR and DD. The spore richness was significantly the highest in LR, followed by SD and DD respectively. The diversity indices too showed a similar trend to total abundance and richness (Table 2).

In the study, spore morphotypes were characterized into Glomus, Acaulospora, Gigaspora and Scutellospora, with the highest prevalence from Glomus spp. (Figure 4). Interestingly, more exclusive spore morphotypes were recorded in LR (13) in comparison to SD (3), while none reported in DD (Figure 5). 


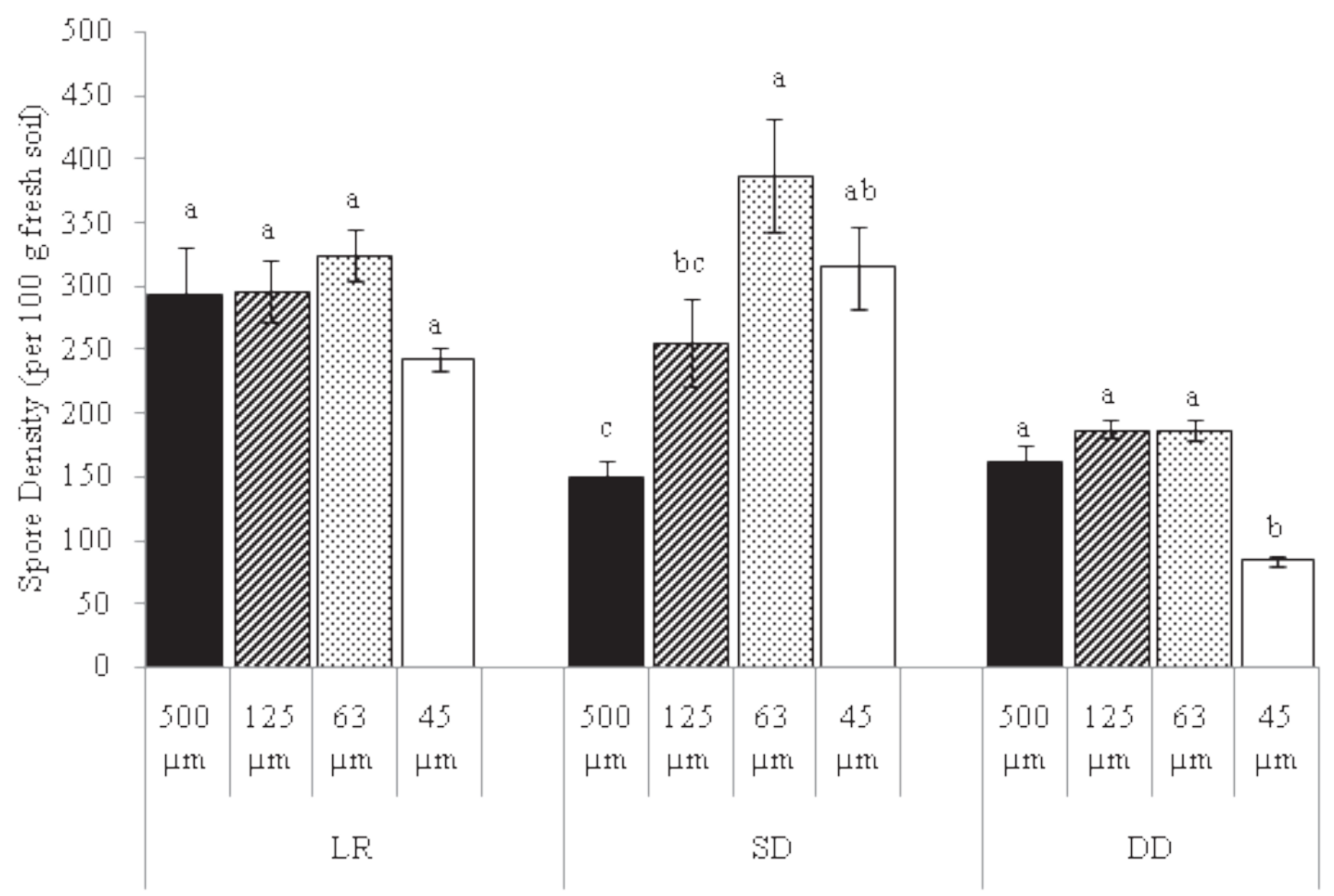

Figure 2: Density of arbuscular mycorrhizal fungal (AMF) spores (per $100 \mathrm{~g}$ fresh soil) under 4 size categories (500, 125, 63 and 45 $\mu \mathrm{m}$ in natural forest (LR), shrub-dominated site (SD) and Dicranopteris dominated fernland (DD) at Kanneliya Forest Reserve, Sri Lanka. Each bar represents an average of 10 soil samples. Vertical bars represent the standard error of means (SEM). The different letters indicate significant differences between means of different size categories in each land use type separately. The results were presented separately for the three land use types for more clarity. ANOVA: $L R, F=1.89, p=0.149 ; \mathrm{SD}=\mathrm{F}=9.25, \mathrm{p}=0.000$ and $\mathrm{DD}, \mathrm{F}=29.99, \mathrm{p}=0.000$.

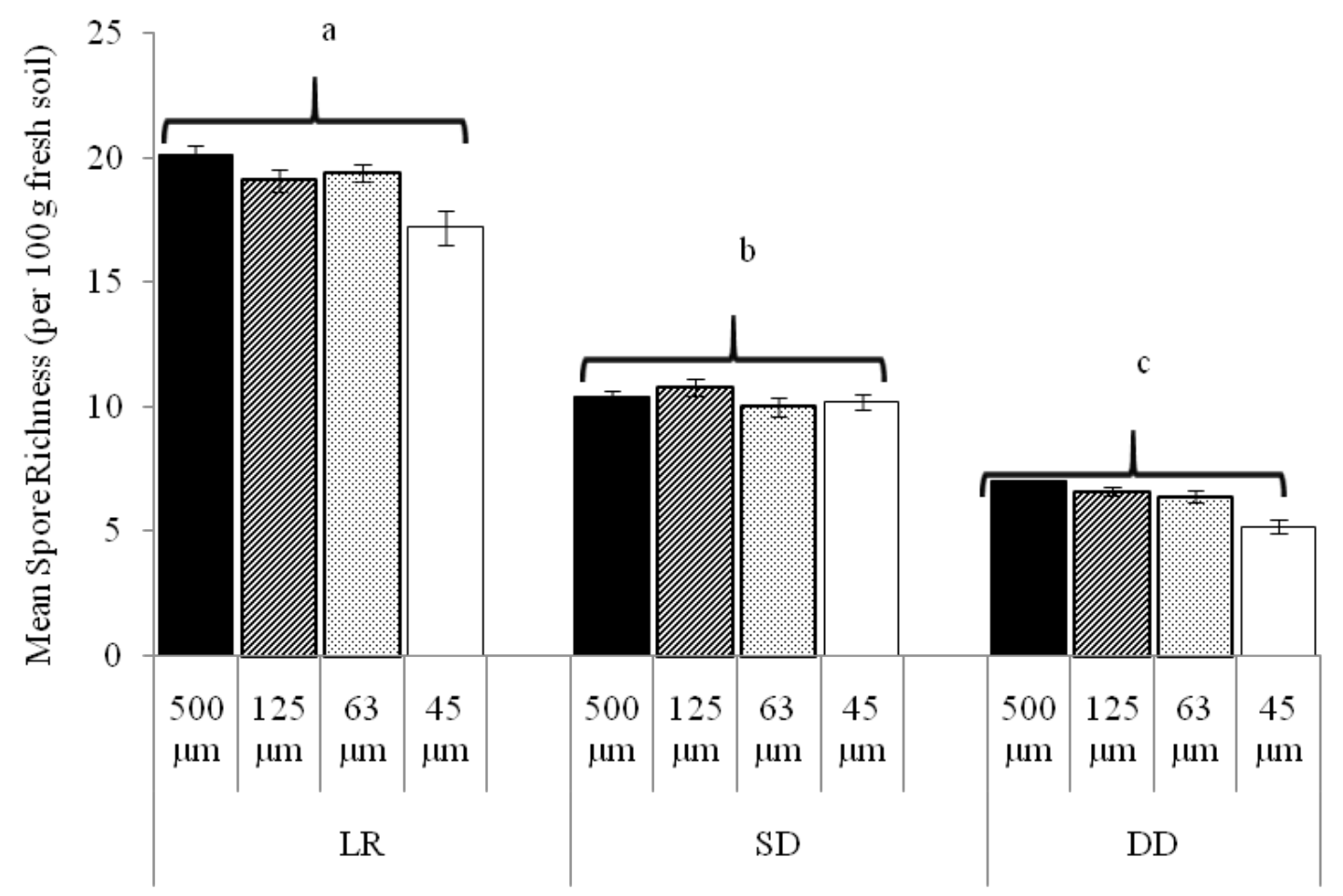

Figure 3: Mean richness of arbuscular mycorrhizal fungal (AMF) spores (per $100 \mathrm{~g}$ fresh soil) under 4 size categories (500, 125, 63 and $45 \mu \mathrm{m}$ in natural forest (LR), shrub-dominated site (SD) and Dicranopteris dominated fernland (DD) at Kanneliya Forest Reserve, Sri Lanka. Each bar represents an average of 10 soil samples. Vertical bars represent the standard error of means (SEM). The different letters indicate significant differences between land use types. In all three land use types, no significant differences were observed in AMF richness between the four size categories. ANOVA: $n=40, F=932.67, p=0.000$. 
A

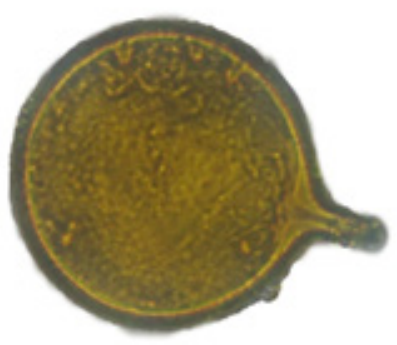

C
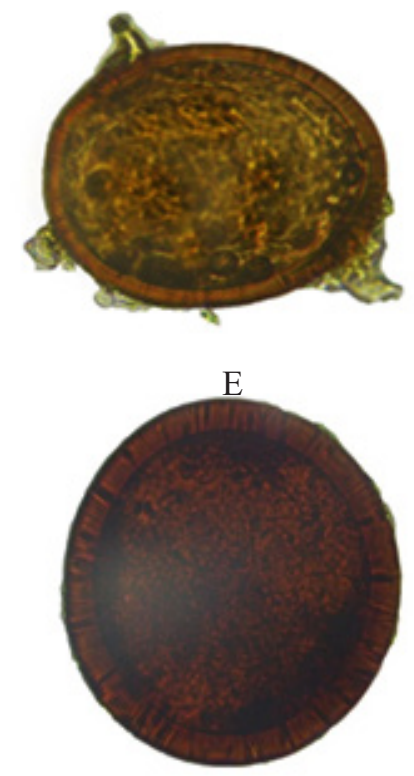

B

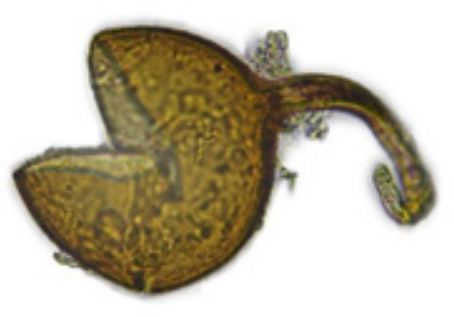

D

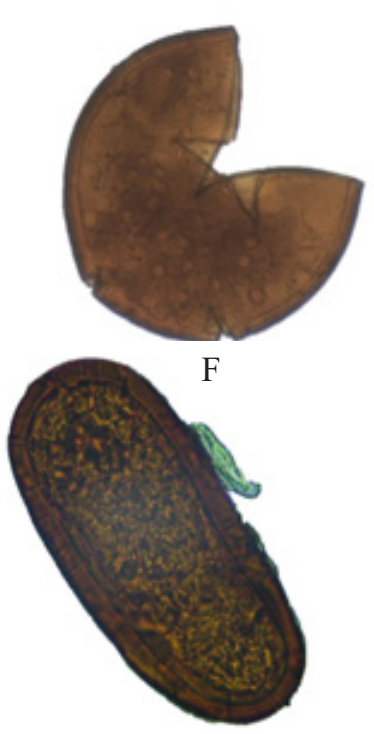

Figure 4: Some AMF spores isolated during the study belonging to Glomus (A-C), Acaulospora (D), Gigaspora (E) and unidentified morphotype (F). Photographs were taken using an Optika Vision Lite 2.13 (at $\times 400$ magnification) microscope.

Table 2: Arbuscular mycorrhizal fungi (AMF) spore characteristics in three land use types, lowland rainforest (LR), shrub-dominated site (SD) and Dicranopteris-dominated fernland (DD) in Kanneliya Forest Reserve in the Sri Lanka

\begin{tabular}{|c|c|c|c|c|c|c|c|c|c|c|c|c|}
\hline \multirow[b]{2}{*}{ Spore Size categories $(\boldsymbol{\mu m})$} & \multicolumn{4}{|c|}{ Lowland Rainforest (LR) } & \multicolumn{4}{|c|}{ Shrub-dominated site (SD) } & \multicolumn{4}{|c|}{ Dicranopteris Fernland (DD) } \\
\hline & $>\mathbf{5 0 0}$ & 125 & 63 & $<45$ & $>\mathbf{5 0 0}$ & 125 & 63 & $<45$ & $>\mathbf{5 0 0}$ & 125 & 63 & $<45$ \\
\hline Abundance & 2,925 & 2,960 & 3,252 & 2,424 & 1,486 & 2,558 & 3,876 & 3,150 & 1,620 & 1,878 & 1,869 & 838 \\
\hline Richness & 21 & 21 & 21 & 20 & 11 & 12 & 12 & 11 & 7 & 7 & 7 & 6 \\
\hline Total Abundance & \multicolumn{4}{|c|}{11,561} & \multicolumn{4}{|c|}{11,070} & \multicolumn{4}{|c|}{6,205} \\
\hline Total Richness & \multicolumn{4}{|c|}{21} & \multicolumn{4}{|c|}{12} & \multicolumn{4}{|c|}{7} \\
\hline S-W Diversity Index & \multicolumn{4}{|c|}{$2.197^{\mathrm{a}}$} & \multicolumn{4}{|c|}{$1.576^{\mathrm{b}}$} & \multicolumn{4}{|c|}{$1.339^{\mathrm{c}}$} \\
\hline Evenness & \multicolumn{4}{|c|}{0.4376} & \multicolumn{4}{|c|}{0.4053} & \multicolumn{4}{|c|}{0.5505} \\
\hline \multicolumn{13}{|l|}{ Jaccard Index } \\
\hline SD vs. DD & \multicolumn{12}{|c|}{$24 \%$} \\
\hline LR vs. DD & \multicolumn{12}{|c|}{$50 \%$} \\
\hline $\begin{array}{l}\text { Mean spore abundance (per } \\
100 \mathrm{~g} \text { fresh soil) }\end{array}$ & \multicolumn{4}{|c|}{$1,156.1^{\mathrm{a}}$} & \multicolumn{4}{|c|}{$1,107.0^{\mathrm{a}}$} & \multicolumn{4}{|c|}{$620.5^{b}$} \\
\hline $\begin{array}{l}\text { Mean spore richness } \\
\text { (per } 100 \mathrm{~g} \text { fresh soil) }\end{array}$ & \multicolumn{4}{|c|}{$20.5^{\mathrm{a}}$} & \multicolumn{4}{|c|}{$11.4^{\mathrm{b}}$} & \multicolumn{4}{|c|}{$7.0^{\mathrm{c}}$} \\
\hline
\end{tabular}

ANOVA: Shannon-Wiener Diversity Index $\mathrm{n}=10, \mathrm{~F}=227.31, \mathrm{p}=0.000$; Mean Spore Abundance, $\mathrm{n}=10, \mathrm{~F}=23.11, \mathrm{p}=0.000$; Mean Spore Richness, $\mathrm{n}=10, \mathrm{~F}=932.67, \mathrm{p}=0.000$. 

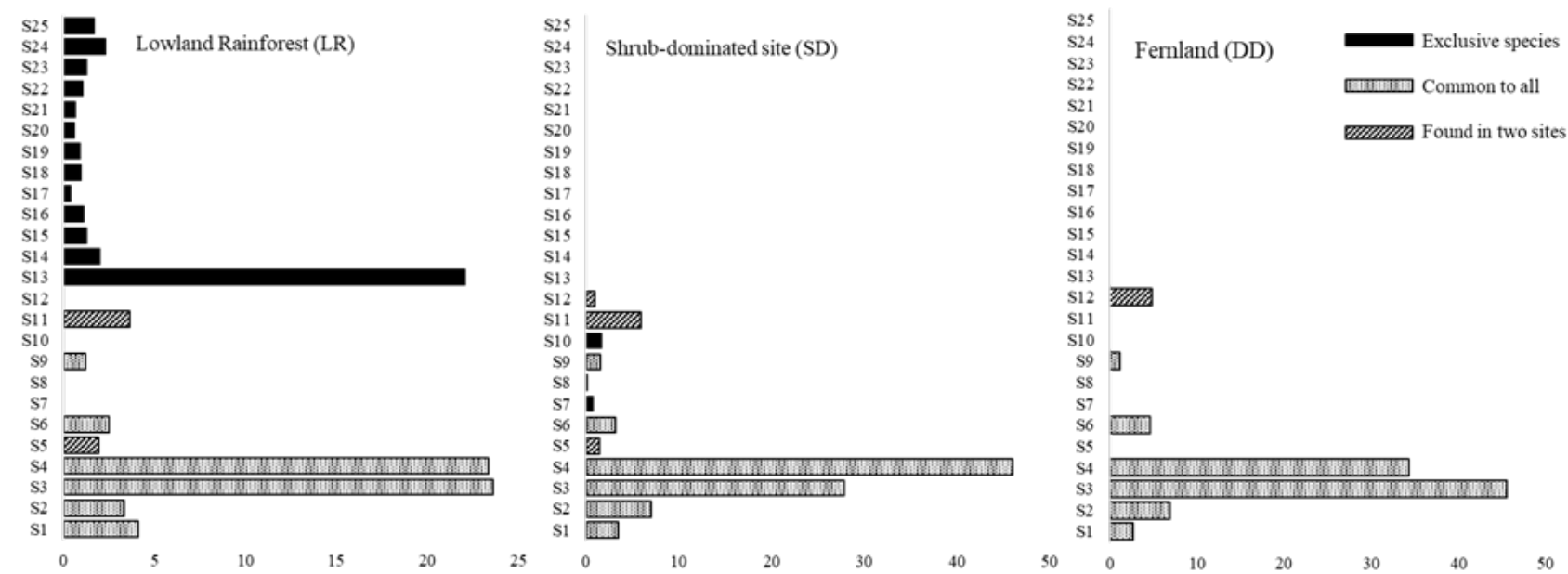

Figure 5: The relative abundance (as a \%) of AMF morphotypes in three land use types; Lowland rain forest (LR), shrub-dominated site (SD) and Dicranopteris-dominated fernland (DD) in Kanneliya Forest Reserve in the Sri Lanka.

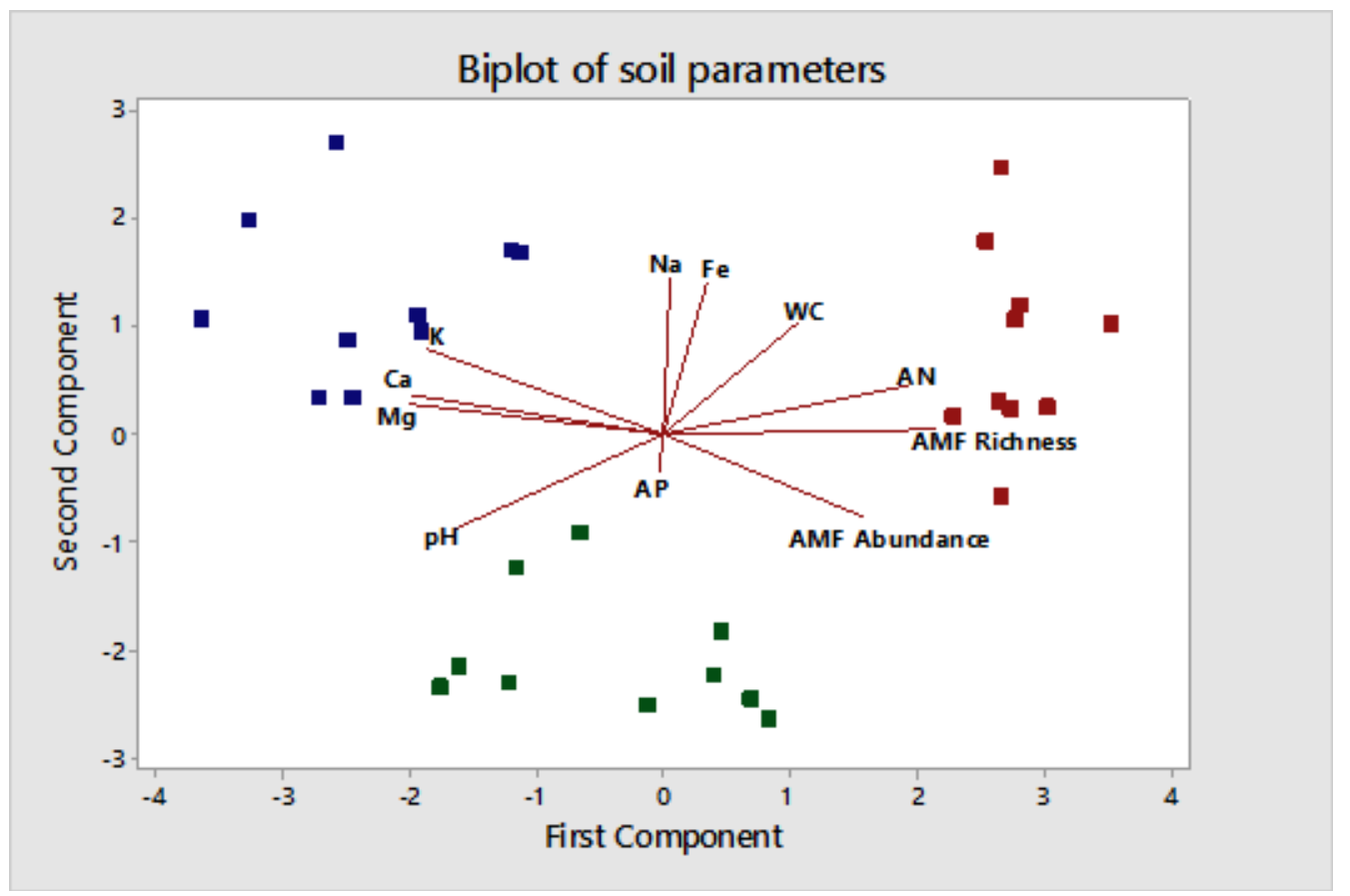

Figure 6: Ordination diagram (drawn with soil parameters, richness and abundance of AMF spores) of the first two components generated in the PCA showing the distinct separation of the three communities, Lowland rainforest (LR), shrub-dominated site (SD) and Dicranopteris-dominated land (DD) in the buffer zone of Kanneliya Forest Reserve, Sri Lanka.

Principal Component Analysis (PCA) showed a clear separation of the three habitat types, indicating their dissimilarities in terms of the abundance and richness of AMF and soil parameters.

\section{DISCUSSION}

\section{Soil resources: nutrients}

Dicranopteris linearis has shown its potential to colonize in nutrient poor sites due to its ability to withstand low resource levels. This is a common trait among exotic invasive species. Being a native species, D. linearis is not categorized as an invasive in the island despite its robust growth due to the misfit in the definition. Furthermore, the shallow rhizomes, exceptionally high phosphorus use efficiency, indeterminate growth and mat-forming capacity are also identified as reasons for their vigorous growth and massive colonization in highly degraded habitats (Russel et al., 1998). Dicranopteris always maintain its dominance by forming a dense mat and suppress the establishment and regeneration of forest species by blanketing the site. Previous studies have noted that changes in organic inputs over a long period of time following changes in land uses may incur impacts on soil properties through altered nutrient processes and dynamics (Guo and Gifford, 2002; Don et al., 2011; Sang et al., 2013; Weissert et al., 2016). Despite higher accumulation of organic matter in fernlands (DD), the soil organic C showed significantly lower levels in DD than that in SD, confirming the highly recalcitrant nature of Dicranopteris litter. However, the soil organic C 
levels in the present study are more or less comparable to findings of a previous study carried out in the Sinharaja Forest, the largest lowland rainforest patch in the island, and fernlands associated with it (Sohng et al., 2017).

The results suggest that fernland soils are inherently poor in nutrients, and except few differences, the fertility status is not differed much from the soils under LR and SD. Previous studies too noted a rather poor soil fertility status at KFR in comparison to other tropical soils under ultisols irrespective of some significant differences between land use types (Perez et al., 2000). Soil available P at KFR is comparatively less than in similar soils at Sinharaja (Sohng et al., 2017). Ultisols, which is the main parental material in the area, are relatively infertile compared to younger volcanic rocks and sediments found in Central America (Baillie et al., 2006). Dicranopteris litter are known to resist decomposition (Vitousek et al., 1994), thus influencing the edaphic characteristics via litter turnover and its quality. The litter layer is biologically the most active, thus a significant fraction of cations can be immobilized when passing through the litter layer (Moslehi, 2010; Shabani, 2013; Moslehi et al., 2019). However, due to the high recalcitrant nature of the fern litter, the immobilization ability is less in the litter layer allowing cations to freely leach into the mineral soil layer. The present study confirmed that most cations are significantly higher in fernlands compared to the other two sites. In fernlands, the litter decomposes well above the soil surface, thus the transplanted seedlings are deprived of $\mathrm{N}$ and $\mathrm{P}$ from the soil-litter system. As a result, the transplanted seedlings grown along strip cuts perform poorly due to lack of major nutrients. The present results too confirmed that the soil available $\mathrm{N}$ is relatively less under Dicranopteris, especially in comparison to the lowland rainforest nearby.

\section{Soil resources: AMF}

Soil microbes play a major driving force behind ecosystem processes, thus playing a critical role in plant growth. The importance of the abundance and diversity of the soil microbiota to ecosystem recovery is well recognized; however, the responses of microbial communities to vegetation restoration and vice versa are poorly understood (Li et al., 2019). The soil microbial community parameters may help to assess the quality of the soil, resilience to degradation and habitats' potential to recover following degradation (Harris, 2003). Of the soil microbiota, fungi play a critical role in the survival of plants and also an integral part of healthy soils (Dubey et al., 2019). The findings of the present study revealed some interesting outcomes in terms of AMF spore abundance, richness and diversity, possibly driven by the single-species dominance in fernlands. The abundance, density and richness of AMF spores was the lowest in fernlands (DD) followed by shrub-dominated landuse (SD) and mature forest (LR). Invasion by exotic species is often associated with shifts in the above-ground vegetation and ecosystem functions (Levine et al., 2003). However, apart from few studies, their impacts on soil microbiota are not well explored (Mummey et al., 2005; Hawkes et al., 2006; Busby et al., 2012; Madawala, 2014). The present scenario is somewhat different to an 'invasion' as $D$. linearis is not an exotic species in the country. However, it is not completely out of context to speculate that the impacts of an invasion on the soil microbiota are more or less comparable to effects caused by a mono-specific dominance by a native species.

Lekberg et al. (2013) showed that AMF richness can even be higher in mono-dominant invasions, thus indicating that above-ground diversity is not always predicts the below-ground AMF richness. In contrast, the present results confirmed that the single-species dominance by $D$. linearis has declined the abundance as well as the richness of AMF populations considerably. Previous studies indicated that Dicranopteris influence the fungal communities more than other groups of microbes (Wu et al., 2011; Zhou et al., 2017). The present study observed approximately 13 exclusive species in the lowland rainforest (LR) while none reported in fernlands, further supporting its negative influence on the AMF population. However, the common species contributed more to the total abundance in all three habitat types. These findings suggest that not only the abundance and richness, but the composition of the AMF community is also altered by the mono-specific dominance of $D$. linearis. Some suggests that AMF-plant associations are not always species specific, but soil properties play a more overriding role in determining their community structures (Opik et al., 2009). According to many evidences, the plant-AMF interactions show little or no partner specificity (Smith and Read, 2008). However, present results indicate some form of host specificity in AMF-plant interactions. In its favor, a previous study too observed a trend of AMF specificity, highlighting the importance of protecting and even promoting the native vegetation in order to maintain the biodiversity in sensitive ecosystems (Torrecillas et al., 2012). However, Davison et al. (2011) suggested that AMF communities are not specific to an individual plant species, but to a specific habitat range.

\section{Soil resources: Implications for restoration}

At present, land degradation is a huge issue worldwide. To restore these degraded ecosystems, countries introduce measures without much success. Invasion of habitats by ferns may suppress other species through shading effect (Holttum, 1938), allelopathy (Gleissman and Muller, 1978; Walker, 1994) or competition for nutrients. Despite efforts to restore fern-invaded lands by physically removing the fern cover, many end in failure. The soil quality determines the potential and the resilience of ecosystems to recuperate following degradation. Soil nutrients and microbiota are two important indicators determining the quality of soil (MAFF, 2000; Arshad and Martin, 2002; Harris, 2003), thus will decide the habitat's ability to recover following a disturbance. Restoring highly degraded tropical forests pose even more challenges as they normally store minerals in their above-ground biomass than in soils. Therefore, tropical soils are generally nutrient-poor, and their nutrient dynamics are more complex than that of nutrient-rich forests (Vitousek et al., 2010; Grau et al., 2017). However, there is a severe dearth of information to determine how the quality of soil impacts restoration efforts. The present results indicate that these fern-dominated habitats lack edaphic 
resources to facilitate the natural succession or to maintain a reasonable growth of introduced tree seedlings/saplings without any restoration interventions. Previous research predicts that mere removal of $D$. linearis may stimulate the natural regeneration. In addition, a study carried out in Sinharaja, the largest lowland tropical rainforest in Sri Lanka, show that any form of soil disturbances could stimulate a non-fern vegetation, though no seedlings of primary forest species were available (Cohen et al., 1995). Russell et al. (1998) too noted that following the removal of $D$. linearis, the area was significantly bare of any vegetation even after 3 years perhaps due to lack of soil resources to support a reasonable vegetation. Therefore, the long-term prevalence of $D$. linearis alters the micro-climate as well as edaphic properties thus creating an oligotrophic condition where the fern gains a competitive advantage over more nutrient-demanding forest species (Russell et al., 1998). The network of roots and the thick litter layer under the $D$. linearis may also prevent soil erosion in the absence of a canopy (Shono et al., 2006). Therefore, the removal of the fern may increase soil temperature, decrease soil moisture and speed up soil erosion (Zhao et al., 2012). These extreme edaphic and microclimatic factors of severely degraded lands may impose significant barriers to natural forest regeneration (Shono et al., 2006). Therefore, even if the $D$. linearis is cleared, the landscape is unable to recover on its own without any interventions. Studies also showed that the removal of $D$. linearis reduces the microbial biomass especially imposing more specific negative influence on fungal communities (Wu et al., 2011; Zhao et al., 2012). Therefore, removing the fern layer may eventually affect the already existing microbiota including AMF, which is considered as one of the major contributory factors to encourage natural succession.

Despite showing some differences between sites, the soils under $D$. linearis dominated landscape are rather low fertile to sustain a good growth of introduced or naturally emerging seedlings. The lowland tropical rainforest soils are too inherently low in nutrients as they generally show tightly controlled and an efficient nutrient cycling process. Lowland tropical rainforests are often found in high rainfall areas and on acidic soils, further making them inherently poor in soil nutrients. Therefore, when these forests are transformed into other vegetation types due to anthropogenic activities, they can become highly impoverished with low chances of recovery on its own.

\section{CONCLUSIONS}

The study showed that the edaphic resources are rather poor in D. linearis dominated habitats, thus the mere removal of the fern layer together with its root mat will make conditions even further degraded over time, with no capacity to sustain a natural or assisted succession. Therefore, anticipating a natural succession or even a reasonable growth of transplanted native tree seedlings is unrealistic without any remedial measures to improve overall micro-habitat conditions in the landscape. Therefore, proper mitigatory measures (i.e., addition of soil amendments) should be carried out before introducing any form of restoration techniques to bring back a non-fern vegetation. Restoration interventions such as addition of an initial dosage of organic/inorganic fertilizer and even biofertilizers could be considered as effective measures to ameliorate the edaphic conditions in order to anticipate any success in restoring these highly degraded landscapes. The selection of suitable species and possible pathways for restoration of acutely degraded rainforests has been comprehensively discussed in Ashton et al., (2001). Their recommendations together with appropriate interventions to improve edaphic conditions could assist restoration practitioners to take more informed decisions to achieve positive outcomes.

\section{ACKNOWLEDGEMENT}

The authors wish to acknowledge the financial support extended by the International Union for Conservation of Nature (IUCN), Sri Lanka.

\section{STATEMENT OF CONFLICT OF INTEREST}

The authors declare no conflict of interest.

\section{REFERENCES}

Akib, M.A., Mustari, K., Kuswinanti, T. and Syaiful, S. A. (2018). Exploration of native mycorrhiza on rhizosphere of Gleichenia linearis in nickel post-mining rehabilitation area of Sorowako, Indonesia. International Journal of Current Research in Biosciences and Plant Biology 5(5): 30-36. doi:10.20546/ijcrbp.2018.505.005

Amatangelo, K.L. and Vitousek, P.M. (2009). Contrasting predictors of fern versus angiosperm decomposition in a common garden. Biotropica 41(2): 154-161. doi:10.1111/j.1744-7429.2008.00470.x

Arshad, M. and Martin, S. (2002). Identifying critical limits for soil quality indicators in agroecosystems. Agriculture, Ecosystems and Environment 88(2): 153-160. doi:10.1016/s01678809(01)00252-3.

Ashton, P.M.S., Gunatilleke, C.V.S., Singhakumara, B.M.P. and Gunatilleke, I.A.U.N. (2001). Restoration pathways for rain forest in southwest Sri Lanka: a review of concepts and models. Forest Ecology and Management 154: 409-430.

Baillie, I.C., Ashton, P.S., Chin, S.P., Davies, S.J., Palmiotto, P. A., Russo, S.E. and Tan, S. (2006). Spatial associations of humus, nutrients and soils in mixed dipterocarp forest at Lambir, Sarawak, Malaysian Borneo. Journal of Tropical Ecology 22(5): 543-553. doi:10.1017/s026646740600352x.

Bandaratillake, H. (2003). Community participation in the management in the Kanneliya-DediyagalaNakiyadeniya proposed biosphere reserve. Journal of the National Science Foundation of Sri Lanka 31(1-2): 139. doi:10.4038/jnsfsr.v31i1-2.3029.

Brundrett, M., Bougher, N., Dell, B., Grove, T. and Malajczuk, N. (1996). Working with Mycorrhizas in Forestry and Agriculture. ACIAR Monograph Issue 32: Canberra, Australia.

Busby, R.R., Paschke, M.W., Stromberger, M.E. and Gebhart, D.L. (2012). Seasonal variation in arbuscular mycorrhizal fungi root colonization of cheatgrass 
(Bromus tectorum), an invasive winter annual. Journal of Ecosystem and Ecography $S, 8$.

Cohen, A.L., Singhakumara, B. and Ashton, P.M. (1995). Releasing rain forest succession: a case study in the Dicranopteris linearis fernlands of Sri Lanka. Restoration Ecology 3(4): 261-270. doi:10.1111/j.1526-100x.1995.tb00093.x

Coutinho, E.S., Fernandes, G.W., Berbara, R.L., Valério, H.M. and Goto, B.T. (2015). Variation of arbuscular mycorrhizal fungal communities along an altitudinal gradient in rupestrian grasslands in Brazil. Mycorrhiza 25(8): 627-638. doi:10.1007/ s00572-015-0636-5.

Davison, J., Öpik, M., Daniell, T.J., Moora, M. and Zobel, M. (2011). Arbuscular mycorrhizal fungal communities in plant roots are not random assemblages. FEMS Microbiology Ecology 78(1): 103-115. doi:10.1111/ j.1574-6941.2011.01103.x.

Don, A., Schumacher, J. and Freibauer, A. (2011). Impact of tropical land-use change on soil organic carbon stocks - a meta-analysis. Global Change Biology 17(4): 1658-1670. doi:10.1111/j.1365-2486.2010.02336.x

Dubey, A., Malla, M.A., Khan, F., Chowdhari, K., Yadav, S., Kumar, A., Sharma, S., Khare, P.K. and Khan, M.L. (2019). Soil microbiome: a key player for conservation of soil health under changing climate. Biodiversity and Conservation 28, 2405-2429. https://doi.org/10.1007/ s10531-019-01760-5

Ekaratne, K., Fernando, R.H.S.S., de Silva, S., Bambaradeniya, C.N.B. and de Silva, D. (2003). A comparison of the conservation and legal status of the fauna and flora of Sri Lanka. IUCN Sri Lanka, Colombo.

FAO (2010a). Report on Technical workshop- Biodiversity in sustainable diets. FAO, Rome. (Available at: http:// www.fao.org/ag/humannutrition/24994-064a7cf9328fb e211363424ba7796919a.pdf, accessed October 2011).

FAO (1997). Current World Fertilizer Situation and Outlook 1994/1995- 2000/2001. FAO/UNIDO/World Bank Working Group on Fertilizers, Rome.

Gliessman, S.R. and Muller, C.H. (1978). The allelopathic mechanisms of dominance in bracken (Pteridium aquilinum) in Southern California. Journal of Chemical Ecology 4(3): 337-362. doi:10.1007/bf00989342.

Gomes, V.M., Negreiros, D., Fernandes, G.W., Pires, A. C., Silva, A.C. and Stradic, S.L. (2017). Long-term monitoring of shrub species translocation in degraded Neotropical mountain grassland. Restoration Ecology 26(1): 91-96. doi:10.1111/rec.12537.

GOSL (Government of Sri Lanka). (2000). National Water Resources Policy and Institutional Arrangements. Colombo, Sri Lanka: Water Resources Council and Secretariat.

Grau, O., Peñuelas, J., Ferry, B., Freycon, V., Blanc, L., Desprez, M., and Hérault, B. (2017). Nutrient-cycling mechanisms other than the direct absorption from soil may control forest structure and dynamics in poor Amazonian soils. Scientific Reports, 7(1): doi:10.1038/ srep45017.

Gunaratne, A.M., Gunatilleke, C.V., Gunatilleke, I.A., H.M.S.P. Madawala Weerasinghe and Burslem, D.
F. (2010). Barriers to tree seedling emergence on human-induced grasslands in Sri Lanka. Journal of Applied Ecology 47(1): 157-165. doi:10.1111/j.13652664.2009.01763.x.

Gunaratne, A., Gunatilleke, C., Gunatilleke, I., Madawala, H. and Burslem, D. (2014). Overcoming ecological barriers to tropical lower montane forest succession on anthropogenic grasslands: Synthesis and future prospects. Forest Ecology and Management 329: 340350. doi:10.1016/j.foreco.2014.03.035

Gunaratne, A., Gunatilleke, C., Gunatilleke, I., Weerasinghe, H.M. and Burslem, D. (2011). Release from root competition promotes tree seedling survival and growth following transplantation into humaninduced grasslands in Sri Lanka. Forest Ecology and Management 262(2): 229-236. doi:10.1016/j. foreco.2011.03.027.

Guo, L.B. and Gifford, R.M. (2002). Soil carbon stocks and land use change: A meta analysis. Global Change Biology 8(4): 345-360. doi:10.1046/j.13541013.2002.00486.x.

Hardwick, K., Healey, J.R., Elliott, S. and Blakesley, D. (2004). Research needs for restoring seasonal tropical forests in Thailand: accelerated natural regeneration. New Forests 27(3): 285-302. doi:10.1023/ b:nefo.0000022228.08887.d2.

Harris, J.A. (2003). Measurements of the soil microbial community for estimating the success of restoration. European Journal of Soil Science 54(4): 801-808. doi:10.1046/j.1351-0754.2003.0559.x.

Hawkes, C.V., Belnap, J., D’Antonio, C. and Firestone, M.K. (2006). Arbuscular mycorrhizal assemblages in native plant roots change in the presence of invasive exotic grasses. Plant and Soil 281(1-2), 369-380. doi:10.1007/s11104-005-4826-3.

Holl, K. D. and Kappelle, M. (1999). Tropical forest recovery and restoration. Trends in Ecology and Evolution 14(10): 378-379. doi:10.1016/s01695347(99)01716-4.

Holttum, R.E. (1938). The ecology of tropical pteridophytes. Manual of Pteridology 420-450. doi:10.1007/978-94-017-6111-6-13.

IUCN, A. (2016). Global Standard for the Identification of Key Biodiversity Areas. Version, 1, 2016-048.

Kollmann, J., Meyer, S.T., Bateman, R., Conradi, T., Gossner, M.M., Mendonça, M.D., and Weisser, W.W. (2016). Integrating ecosystem functions into restoration ecology-recent advances and future directions. Restoration $\quad$ Ecology 24(6): $\quad$ 722-730. doi:10.1111/rec.12422.

Jayasuriya, A.H.M. and Abayawardena, S.D. (2008). A study to determine the changes in the biodiversity values of southern Sinharja and Kanneliya forests after the implementation of GEF medium sized project, Integrated development association (IDEA) Kundasale.

Lekberg, Y., Gibbons, S.M., Rosendahl, S. and Ramsey, P.W. (2013). Severe plant invasions can increase mycorrhizal fungal abundance and diversity. The ISME Journal 7(7), 1424-1433. doi:10.1038/ismej.2013.41.

Levine, J. M., Vilà, M., Antonio, C. M., Dukes, J. S., Grigulis, K. and Lavorel, S. (2003). Mechanisms underlying 
the impacts of exotic plant invasions. Proceedings of the Royal Society of London. Series B: Biological Sciences 270(1517): 775-781. doi:10.1098/ rspb.2003.2327.

Li, H., Su, J., Yang, X. and Zhu, Y. (2019). Distinct rhizosphere effect on active and total bacterial communities in paddy soils. Science of The Total Environment 649, 422-430. doi:10.1016/j. scitotenv.2018.08.373.

Lindström, S., Mattsson, E. and Nissanka, S. (2012). Forest cover change in Sri Lanka: The role of small scale farmers. Applied Geography 34: 680-692. doi:10.1016/j.apgeog.2012.04.011.

Lovelock, C.E. and Ewel, J.J. (2005). Links between tree species, symbiotic fungal diversity and ecosystem functioning in simplified tropical ecosystems. New Phytologist 167(1): 219-228. doi:10.1111/j.14698137.2005.01402.x.

Lugo, A.E. (1988). Estimating reductions in the diversity of tropical forest species. Biodiversity. Washington, D.C.: National Academy Press, Pp. 58-70.

Madawala, H.M.S.P. (2014). Austroeupatorium inulifolium invasion increases arbuscular mycorrhizal abundance in Cymbopogon-dominated grasslands in Knuckles Conservation Area. Journal of National Science Foundation of Sri Lanka 42(4): 361-364. doi: 10.4038/ jnsfsr.v42i4.7735.

MAFF, V. (2000). National food survey 1999. Annual report, MAFF-Ministry of Agriculture.

Maheswaran, J. and Gunatilleke, I.A. (1988). Litter decomposition in a lowland rain forest and a deforested area in Sri Lanka. Biotropica 20(2): 90. doi:10.2307/2388180.

Moslehi, M., Habashi, H., Khormali, F., Ahmadi, A., Brunner, I. and Zimmermann, S. (2019). Base cation dynamics in rainfall, throughfall, litterflow and soil solution under Oriental beech (Fagus orientalis Lipsky) trees in northern Iran. Annals of Forest Science 76: 55. doi.org/10.1007/s13595-019-0837-8.

Moslehi, M. (2010). The effect of beech species on basecation dynamics in mixed Hyrcanian beech forest, Shastkolate. Dissertation, Gorgan University of Agricultural Sciences and Natural Resources.

Mummey, D. L., Rillig, M. C. and Holben, W. E. (2005). Neighboring plant influences on arbuscular mycorrhizal fungal community composition as assessed by T-RFLP analysis. Plant and Soil 271(1-2): 83-90. doi:10.1007/ s11104-004-2066-6.

Negishi, J., Sidle, R., Noguchi, S., Nik, A.R. and Stanforth, R. (2006). Ecological roles of roadside fern (Dicranopteris curranii) on logging road recovery in Peninsular Malaysia: preliminary results. Forest Ecology and Management 224(1-2): 176-186. doi:10.1016/j.foreco.2005.12.017.

Öpik, M., Metsis, M., Daniell, T.J., Zobel, M. and Moora, M. (2009). Large-scale parallel 454 sequencing reveals host ecological group specificity of arbuscular mycorrhizal fungi in a boreonemoral forest. New Phytologist 184(2): 424-437. doi:10.1111/j.14698137.2009.02920.x.

Pérez, T., Trumbore, S.E., Tyler, S.C., Davidson, E.A.,
Keller, M., and Camargo, P.B. (2000). Isotopic variability of $\mathrm{N}_{2} \mathrm{O}$ emissions from tropical forest soils. Global Biogeochemical Cycles 14(2): 525-535. doi:10.1029/1999gb001181.

Russell, A.E. and Vitousek, P.M. (1997). Decomposition and potential nitrogen fixation in Dicranopteris linearis litter on Mauna Loa, Hawaii. Journal of Tropical Ecology 13(4): 579-594. doi: 10.1017/s0266467400010737.

Russell, A.E., Raich, J.W. and Vitousek, P.M. (1998). The ecology of the climbing fern Dicranopteris linearis on windward Mauna Loa, Hawaii. Journal of Ecology 86(5): 765-779. doi:10.1046/j.13652745.1998.8650765.x.

Russell, A.E., Ranker, T.A., Gemmill, C.E. and Farrar, D.R. (1999). Patterns of Clonal Diversity in Dicranopteris linearis on Mauna Loa, Hawaii1. Biotropica 31(3): 449-459. doi:10.1111/j.1744-7429.1999.tb00387.x.

Sang, P. M., Lamb, D., Bonner, M. and Schmidt, S. (2013). Carbon sequestration and soil fertility of tropical tree plantations and secondary forest established on degraded land. Plant and Soil 362(1-2): 187-200. doi:10.1007/s11104-012-1281-9.

Shabani, E. (2013). Base cation dynamic in throughfall and forest floor leaching of Acer velutinum (Velvet maple), Carpinus betulus (hornbeam) and Quercus castanifolia (Chestnut leaved oak) in the mixed HornbeamIronwood forest stand. Dissertation, Gorgan University of Agricultural Sciences and Natural Resources.

Shono, K., Davies, S.J. and Kheng, C.Y. (2006). Regeneration of native plant species in restored forests on degraded lands in Singapore. Forest Ecology and Management 237(1-3): 574-582. doi:10.1016/j. foreco.2006.10.003.

Singhakumara, B.M.P. (1995). Ecological assessment of Kanneliya, Dediyagala-Nakiyadeniya (KDN) forest complex. Department of Forestry and Environmental Science, University of Sri Jayewardenepura, Nugegoda.

Smith, S.E. and Read, D. (2008). Colonization of roots and anatomy of arbuscular mycorrhizas. Mycorrhizal Symbiosis 42-90. doi:10.1016/b978-0123705266.50004-0.

Sohng, J., Singhakumara, B.M.P. and Ashton, M.S. (2017). Effects on soil chemistry of tropical deforestation for agriculture and subsequent reforestation with special reference to changes in carbon and nitrogen. Forest Ecology and Management 389: 331-340. doi:10.1016/j. foreco.2016.12.013.

Susanti, A.T. A., Isda, M.N. and Fatonah, S., (2014). Potensi alelopati ekstrak daun Gleichenia linearis (Burm.) Underw. terhadap perkecambahan dan pertumbuhan anakan gulma Mikania micrantha (L.) Kunth. JOM FMIPA 1: 1-7.

Tet-Vun, C., and Ismail, B.S. (2006). Field evidence of the allelopathic properties of Dicranopteris linearis. Weed Biology and Management 6(2), 59-67. doi:10.1111/ j.1445-6664.2006.00203.x.

Torrecillas, E., Alguacil, M.M. and Roldán, A. (2012). Host preferences of arbuscular mycorrhizal fungi colonizing annual herbaceous plant species in semiarid mediterranean prairies. Applied and Environmental Microbiology 78(17): 6180-6186. doi: 10.1128/ 
aem.01287-12.

Uhl, C. (1988). Restoration of degraded lands in the Amazon Basin. Biodiversity. National Academy Press, Washington, DC, Pp. 326-332.

Uhl, C. and Jordan, C.F. (1984). Succession and nutrient dynamics following forest cutting and burning in Amazonia. Ecology 65(5): 1476-1490. doi:10.2307/1939128.

Uhl, C., Clark, K., Dezzeo, N. and Maquirino, P. (1988). Vegetation dynamics in Amazonian treefall gaps. Ecology 69(3): 751-763. doi:10.2307/1941024

Van Reeuwijk, L. P. (1993). Procedures for Soil Analysis. International Soil Reference and Information Centre (ISRIC). Wageningen. Netherlands.

Vitousek, P.M., Porder, S., Houlton, B.Z. and Chadwick, O.A. (2010). Terrestrial phosphorus limitation: Mechanisms, implications, and nitrogen-phosphorus interactions. Ecological Applications 20(1): 5-15. doi:10.1890/08-0127.1.

Vitousek, P.M., Turner, D.R., Parton, W.J. and Sanford, R.L. (1994). Litter decomposition on the Mauna Loa environmental matrix, Hawai'i: patterns, mechanisms, and models. Ecology 75(2): 418-429. doi:10.2307/1939545.

Walker, L.R. (1994). Effects of fern thickets on woodland development on landslides in Puerto Rico. Journal of Vegetation Science 5(4): 525-532. doi: $10.2307 / 3235979$.

Weissert, L., Salmond, J., Turnbull, J. and Schwendenmann, L. (2016). Temporal variability in the sources and fluxes of $\mathrm{CO}_{2}$ in a residential area in an evergreen subtropical city. Atmospheric Environment 143: 164176. doi:10.1016/j.atmosenv.2016.08.044.

Weerasinghe, M., Ashton, M.S., Hooper, E.R. and Singhakumara, B.M.P. (2018). Floristics of soil seed banks on agricultural and disturbed land cleared of tropical forests. Restoration Ecology 27(1): 138-147. https://doi.org/10.1111/rec.12711.

Wu, J., Liu, Z., Wang, X., Sun, Y., Zhou, L., Lin, Y. and Fu, S. (2011). Effects of understory removal and tree girdling on soil microbial community composition and litter decomposition in two Eucalyptus plantations in South China. Functional Ecology 25(4): 921-931. doi:10.1111/j.1365-2435.2011.01845.x.

Zhao, J., Wan, S., Fu, S., Wang, X., Wang, M., Liang, C. and Zhu, X. (2013). Effects of understory removal and nitrogen fertilization on soil microbial communities in Eucalyptus plantations. Forest EcologyandManagement 310: 80-86. doi:10.1016/j.foreco.2013.08.013.

Zhao, J., Wan, S., Li, Z., Shao, Y., Xu, G., Liu, Z., and Fu, S. (2012). Dicranopteris-dominated understory as major driver of intensive forest ecosystem in humid subtropical and tropical region. Soil Biology and Biochemistry 49: 78-87. doi:10.1016/j.soilbio.2012.02.020.

Zhou, Y., Zhu, H., Fu, S. and Yao, Q. (2017). Variation in soil microbial community structure associated with different legume species is greater than that associated with different grass species. Frontiers in Microbiology 8: 1007. doi: 10.3389/fmicb.2017.01007.

Zheng, H., Chen, F., Ouyang, Z., Tu, N., Xu, W., Wang, X. and Tian, Y. (2008). Impacts of reforestation approaches on runoff control in the hilly red soil region of Southern China. Journal of Hydrology 356(1-2): 174-184. doi:10.1016/j.jhydrol.2008.04.007. 